\title{
The Oral Glucose Tolerance Test: A Study of the Influence of Age on the Response to the Standard Oral $50 \mathrm{~g}$ Glucose Load
}

\author{
J.P. Ladvaux and M. Staquet
}

Clinique Médicale, Hôpital Universitaire Saint-Pierre (Prof. P.A. Bastenie), Université Libre de Bruxelles, Belgique

Received: September 10, 1969

Summary. 160 women and 133 men over 50 were chosen for the experiment. They were divided into three age groups. In order to study a group of subjects who were normal for their age, caution was taken to discard known overt diabetics and to avoid any interfering factor that might influence glucose tolerance. The results are expressed by the median and the 5th and 95th percentiles. The median increases progressively with age. There is a highly significant difference between subjects over and under 65 , but none between sexes. The 5th percentile varies very little whereas the 95 th percentile shows a large increase. This is more evident in women than in men. This would indicate an increased prevalence of diabetes with age rather than a general reduction of glucose tolerance. The therapeutic problems are discussed. -

Influence de l'âge sur l'épreuve d'hyperglycémie par administration orale de $50 \mathrm{~g}$ de glucose

Résumé. L'expérimentation porte sur 160 femmes et 133 hommes de plus de 50 ans répartis en 3 classes d'âge. L'étude d'une population âgée normale a nécessité l'ex. clusion des diabétiques avérés et de tout facteur diabétogène possible. Les résultats sont exprimés par la médiane et les percentiles 5 et 95. La médiane augmente progressivement avec l'âge; la différence entre les sujets de plus et de moins de 65 ans est hautement significative, sans variation statistique entre les sexes. Le percentile 5 évolue très peu, par contre on observe une augmentation im- portante des valeurs du percentile 95 ; cet aspect est plus marqué chez les femmes. Ces données démontreraient une fréquence croissante du diabète avec l'âge plutôt qu'une diminution générale de la tolérance au glucose. L'implication thérapeutique est discutée.

Beeinflussung der oralen Glucosebelastung (mit $50 \mathrm{~g}$ Glucose) durch das Alter

Zusammenfassung. Die Untersuchung bezog sich auf 160 Frauen und 133 Männer über 50, verteilt auf drei Altersgruppen. Um ein normales Bevölkerungsmuster zu untersuchen, wurden bekannte, manifeste Diabetiker und Patienten mit diabetischer Veranlagung ausgeschlossen. Die Resultate wurden ausgedrückt in Medianen und den Perzentilen 5 und 95. Der Median steigt allmählich mit dem Alter. Es existiert ein hoch signifikanter Unterschied zwischen den Altersklassen über und unter 65, aber nicht zwischen beiden Geschlechtern. Das Perzentil 5 schwankt wenig, das Perzentil 95 hingegen steigt stark. Dies ist ausgesprochener bei Frauen als bei Männern der Fall. Dieses würde dann eher eine steigende Frequenz des Diabetes mit dem Alter bedeuten, als eine allgemein verringerte Glucosetoleranz. Die therapeutische Bedeutung wird besprochen.

Key-words: Diabetes, chemical diabetes, glucose tolerance, aging and glucose tolerance, plasma glucose distribution, plasma glucose normal limits.
The oral glucose tolerance test (O.G.T.T.) remains the best and the most convenient test for the diagnosis of diabetes mellitus in subjects without fasting hyperglycaemia [33]. Differences in techniques, absence of caution in avoiding interfering factors and difficulty in establishing normal limits have led to some confusion in the interpretation of the test. Conditions recommended for the conduct of the test [40] and criteria of normality for the different methods are now available [17]. These criteria, however, are open to criticism: distinction between normal subjects and chemical diabetics [38] remains arbitrary [8,9], and progressive reduction of carbohydrate tolerance with advancing age $[1,2,3,4,7,10,11,14,17,20,21,22,23,25,37$, $39,43,44,45,46,47,49,50]$ is not taken into account. This reduction of carbohydrate tolerance with age appears to some authors to be so general, that they think it reasonable to make the criteria of normality age-dependent $[4,7,22,37,49]$.

The aim of this study is twofold:

1. How far does glucose tolerance decrease with age in a normal population?
2. To what extent is this phenomenon physiological ?

\section{Material and Methods}

293 subjects, 160 women and 133 men over 50, were chosen for the study. They were divided into three age groups: 50 to 64,65 to 79,80 and over ('Table). The youngest group was recruited among factory workers and the other two from an old people's home.

Table. Age and sex distribution of the subjects

\begin{tabular}{lcccc}
\hline $\mathrm{A}$ & $50-64$ & $65-79$ & $\geq 80$ & total \\
\hline $\mathrm{M}$ & 48 & 54 & 31 & $\mathbf{1 3 3}$ \\
$\mathrm{F}$ & 52 & 51 & 57 & 160 \\
& 100 & 105 & 88 & 293 \\
\hline
\end{tabular}

Known diabetics were excluded from the study. The incidence of overt diabetes in the population from which our subjects were selected was estimated at $4.0 \%, 9.0 \%$, and $3.6 \%$ for the men and $5.4 \%, 13.0 \%$, $12.0 \%$ for the women in each age group respectively. Before our study, all the subjects had had yearly 
check-ups, including enzymatic tests for postprandial glucosuria or determination of the fasting blood glucose. None of them had a positive glycosuria or a fasting blood sugar higher than $105 \mathrm{mg} / 100 \mathrm{ml}$ [whole blood, Technicon autoanalyser, Method of Hoffman, W. S. [24]]. They had no acute disease nor had they any chronic impairment of liver or kidney function, and they were not taking drugs that might influence carbohydrate metabolism. Most of these persons were within normal limits of ideal body weight; $9.2 \%$ had $10 \%$ of ideal body weight in excess, $13 \%$ presented a mean excess of $25 \%$ and only $1.3 \%$ weighed $10 \%$ less than their ideal body weight (18). All but a few subjects were normally active. The factory workers obviously had regular physical exercise, but so also did most of the older persons, who were walking around or going out every day. Only $10.3 \%$ of the subjects of the two older groups were more or less confined to a chair. These last patients, however, received regular physiotherapy. Family histories of diabetes were not noted because of the difficulty subjects might have in recalling the facts with certainty.

The subjects received a standard O.G.T.T. $(50 \mathrm{~g}$ glucose in $200 \mathrm{ml}$ water). They were given a diet with a sufficient amount of carbohydrate (200 to $250 \mathrm{~g}$ minimum) during the preceding days. The test was performed after an overnight fast, and the patients rested in bed throughout. Blood samples were collected from a forearm vein before the administration of glucose and 30, 60, 90 and 120 min after it.

The determination of the plasma glucose levels was made by the method of Hoffman [24] adapted to the Technicon Autoanalyzer. The conventional normal values of the O.G.T.T. obtained with the same method as ours, but with the use of whole blood, are, according to Fitzgerald and Keen [16] $160 \mathrm{mg} / 100 \mathrm{ml}$ for the peak and $110 \mathrm{mg} / 100 \mathrm{ml}$ for the two hour value. The conversion factor being blood glucose concentration = 0.89 plasma glucose concentration [31], these values become 179 and $123 \mathrm{mg} / 100 \mathrm{ml}$.

The precision of the method was assessed by duplicate measurements of glucose concentration on the same plasma in eleven patients at two levels: less than $150 \mathrm{mg} / 100 \mathrm{ml}$ and more than $150 \mathrm{mg} / 100 \mathrm{ml}$. The coefficients of variation were $0.67 \%$ for the low value and $2.95 \%$ for the high value. The results were analyzed by an I.B.M. 70-40 computer.

\section{Results}

The plasma glucose distribution was examined by means of histograms for both sexes, for the three age groups and for each point of the O.G.T.T.

Most of the curves had a long tail to the right and could be said to be positively skewed (Figs. 1 and 2), and several showed too many values grouped together near the mean and could be described as leptocurtic, as indicated by computation of the third and fourth moment about the mean.
Since the distribution did not show a normal pattern, the conventional statistical analysis was not valid. Consequently the usual method of computing means and standard deviations to assess normal limits, was replaced by the median and percentile values.

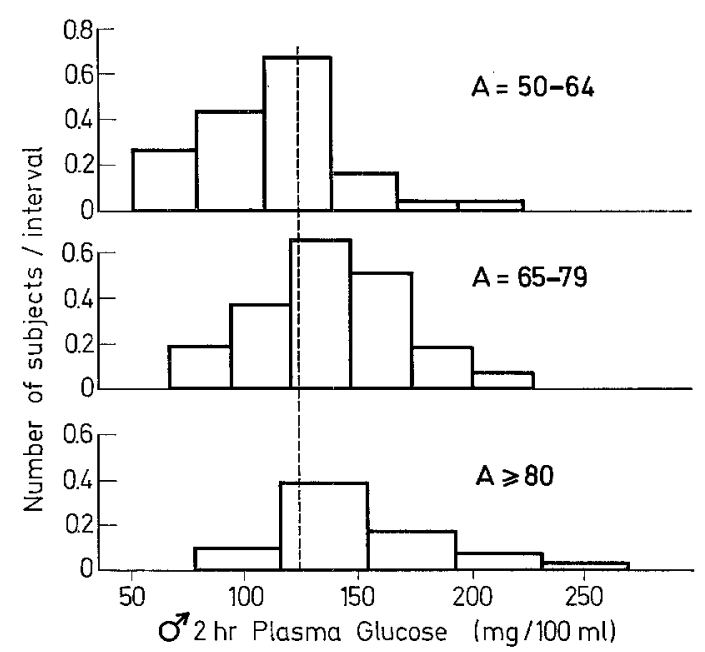

Fig. 1. Histograms of the two-hour plasma glucose value for males in the three age groups. The dotted line separates the curves at the conventional limit of normality. It will be noticed that there is no natural division at this or any other line

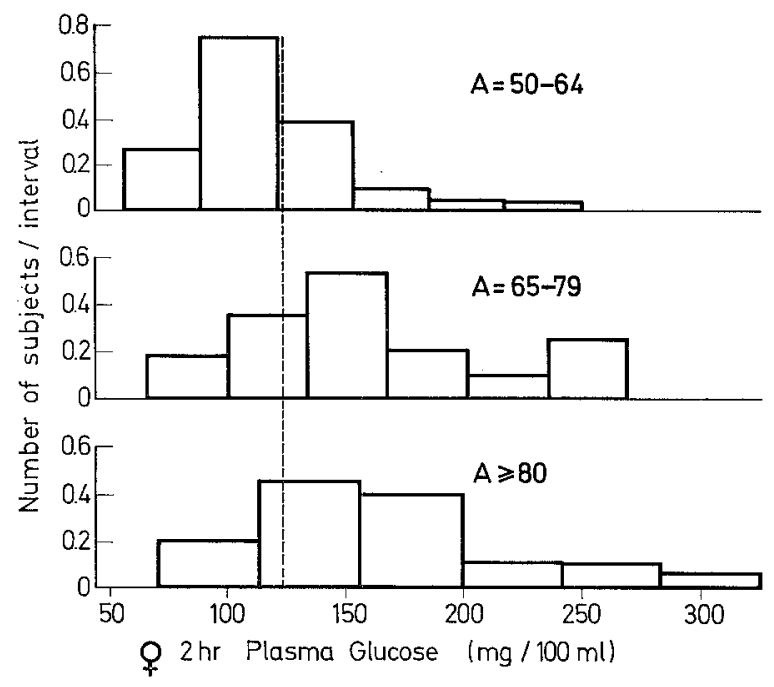

Fig. 2. As in Fig. 1 but for females

Sex-specific O.G.T.T.

Fig. 3 shows the median for both sexes, irrespective of age. The two curves are very similar up to the 60th min, when the peak is reached. The decrease thereafter seems faster in men. However, no significant difference was found at any time between the two groups (median test).

Age-specific O.G.T.T.

As seen in Fig. 4, which gives the median values, there is a clear-cut difference between the curves for 
subjects above 65 years and that for subjects under this age. The peak in the youngest group is reached at the 30 th $\mathrm{min}$, whereas this occurs only at the 60 th $\mathrm{min}$ in the older groups. Afterwards the decrease is steeper

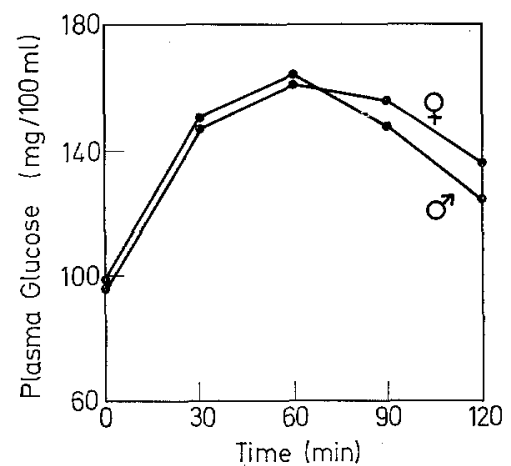

Fig. 3. Median curves of males and females irrespective of age

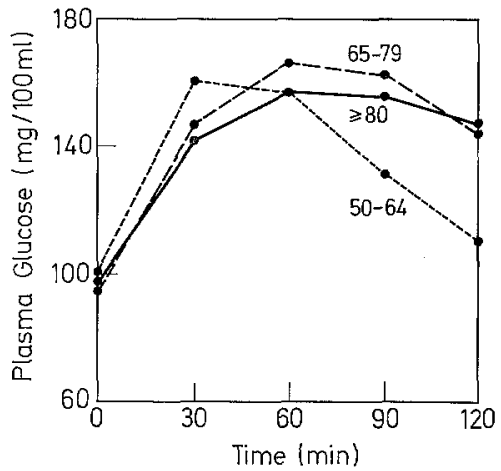

Fig. 4. Median curves in the three age groups irrespective of sex

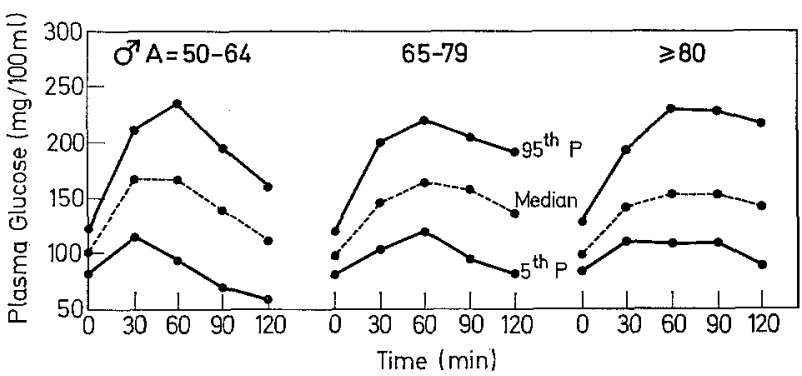

Fig. 5. Male's 5th percentile, median and 95 th percentile curves in the three age groups

under 65 , in sharp contrast with the slope of the curves of the older subjects. Statistical analysis shows a highly significant difference $(p<0.001)$ between subjects over and under 65 at 90 and 120 min (median test).

Age-and sex-specific O.G.T.T.

Figs. 5 and 6 show the difference between the six groups, pointing out the progressive impairment of the O.G.T.T. with advancing age. There is again no significant difference between sexes in each age group (median test).
Dispersion of the values, as estimated by the 5th and 95 th percentiles, is greater in women than in men, and in each sex it increases as the subjects become older.

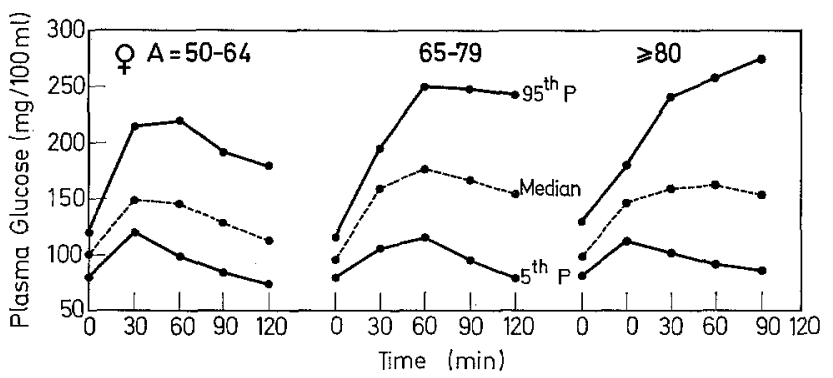

Fig. 6. As in Fig. 5 but for females

\section{Discussion}

When does glucose tolerance start to be abnormal

The delineation between normal subjects, chemical diabetics and overt diabetics is quite arbitrary. The normal limits are usually established by computation of means and standard deviations $[19,28,33]$, or by validation of the chosen criteria based on the study of the number of values above and below the adopted limits recorded among subjects with and without a family history of diabetes $[13,15]$.

Our own results (Figs. 1 and 2) like those already published $[2,8]$, do not show bimodality, and therefore do not permit a clear-cut separation between normal subjects and diabetics. It thus seems impossible to assess the magnitude of type 1 (false positive) and type 2 (false negative) errors.

Figs. 1 and 2 clearly show that any dividing line between "normality" and "diabetes" can only be conventional. In this matter, as in so many other biological conditions such as hypertension [36], there is no sharp division between normal and abnormal.

Two facts however must be borne in mind:

1. The existence of the clinical entity of overt diabetes with all its complications.

2. The frequent transformation of chemical diabetes into overt diabetes $[13,15,34,51]$. Both justify the use of an arbitrary limit.

The only way to find the best dividing line is a prospective study like that carried out by O'Sullivan [34].

This can be done with young subjects, less easily with older ones, and certainly not with a very old population because of its shorter life expectancy.

\section{Decrease of glucose tolerance with age.}

Although in our selected material the subjects could be classified in advance as "normal", this study confirms the decrease of glucose tolerance with advancing age. No significant difference between sexes was found. This is in agreement with other authors $[10,21]$. Only increasing age can explain the decrease in 
glucose tolerance in our sample; for sufficient intake of carbohydrate during the days preceding the test was assured; there were only a few cases of obesity and these were not outstanding; no disease was present, and no drugs were taken, that in either case was likely to alter the glucose tolerance, and there was sufficient physical activity. This last factor could not have influenced the results of the first group which was composed of very active persons, and which, however, already showed impairment of glucose tolerance. In the older groups, too few subjects had decreased activity for this to have influenced the results; and, moreover, this factor might have been overemphasized $[10,23]$. Furthermore, it is a more or less normal feature of aging [49].

A general trend or a segregation of diabetics with advancing age?

Figs. 5 and 6 show that the increase of the value of the 5th percentile with age is not very marked and contrasts with a more pronounced increase of that of the 95th percentile. This also appears in Fig. 7, which

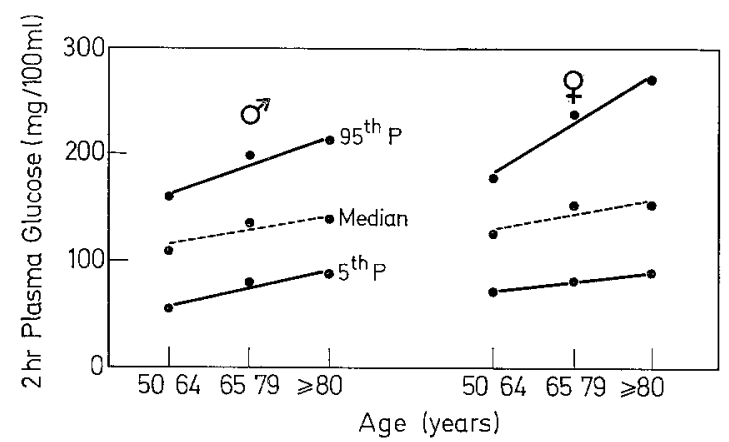

Fig. 7. Regression lines with age of the O.G.T.T. twohour plasma glucose value for the 5th percentile, the median and the 95 th percentile

shows the regression lines of the O.G.T.T.two-hour value with age for the 5th percentile, the median and the 95 th percentile. The 5th percentile and the median regression lines are almost parallel, whereas that of the 95th percentile diverges, following a steeper slope. This is more evident in women than in men. The same phenomenon was already apparent in Figs. 1 and 2, which show the histograms of the two-hour plasma glucose value in both sexes at the different ages. It will be seen that as age advances, higher values tend to occur for the first time or with an increasing frequency, the very low values tend to disappear and the low values decrease in frequency. The extension of the two-hour plasma glucose to higher values is greater and seems more significant, however, than its recession from lower values.

This means that plasma glucose tends to rise with age, but that the rate of the rise is greater in some subjects than in others. These facts could be due to a reduced tissue permeability for glucose occurring with aging, as is suggested by the response to intravenous glucose and to intravenous insulin [3, 44].

Aging seems a diabetogenic factor to which individuals adapt themselves to different degrees. A proportion of the population maintains a fairly good glucose tolerance even after 80 , whereas the remainder becomes more and more hyperglycaemic with glucose tolerance curves typical of chemical or even of overt diabetes.

The shift to a high blood glucose value with age might be interpreted as resulting from a slight decrease of glucose tolerance in all subjects plus a tremendous development of diabetes in many of them. This fits with the well-known increased prevalence of overt diabetes in old age $[26,35,41]$. The absence of any difference between sexes as judged by the median curves, but the greater dispersion of the bigh values among women as seen by the 95 th percentile [Figs. 5, $6,7)$, is in keeping with the higher frequency of maturity-onset diabetes in the female sex [26].

\section{Practical remarks}

The question is: should old patients with borderline diabetes be treated and how? [27]

Although the eventual risk of a subject with chemical diabetes developing overt diabetes in time varies greatly with the severity of the criteria used [34], this risk remains serious $[13,15,34,51]$. With regard to this danger, the discovery of a chemical diabetes, however, is evidently less significant in old people than in young ones.

Another risk is the increased frequency of cardiovascular diseases among chemical diabetics reported in several studies [8, 27, 35]. Even if this fact, which is not universally admitted [11, 42], is true, nobody knows at what level elevated blood glucose becomes harmful [27].

For these reasons, before deciding to treat elderly patients having an abnormal O.G.T.T., it seems wise first to retest their blood sugar two hours after one of their usual meals containing starch. Indeed, the blood glucose curve in young subjects is approximately the same whether the carbohydrate load is glucose or starch, whereas in old people glucose is far less well tolerated than the same amount of starch [49].

Finally, if a therapeutic decision has to be taken, it should only be a dietetic one in most cases, especially among older patients, since too energetic treatments with sulphonylureas might be more harmful than beneficial $[29,30]$. However, biguanides not liable to induce hypoglycaemia, might be used without danger.

Acknowledgements. We wish to thank the Direction of the Ets. D'Teteren Frères S.A. and Dr. Van Heers. wynghels, medical Director of "La maison de retraite de l'infirmerie", who enabled us to find the subjects for the study. We also thank Misses Mortaignies and Roenen and Mrs Belot, Geelen and Felix for their technical assistance. Our gratitude goes to Prof. P.A. Bastenie, Prof. V. Conard. and Dr. J. Pirart for useful advice. 


\section{References}

1. Balodimos, M.C., Balodimos, P.M., Davis C.B., Belleau, R., Joshi, P.C., Kusakcioglu, O.: Abnormal carbodyhdrate tolerance and diabetes in elderly persons. Geriatrics 22, $159-166$ (1967).

2. Balter, A.M.: Glucose tolerance curves in neuropsychiatric patients. Diabetes 10, 100-104 (1961).

3. Bastenie, P.A., Conard, V., Franckson, J.R.M., Bellens, R., Malaisse, W.: Exploration des états prédiabetiques. Bull. Acad. roy. Méd. Belg. 3, 185-219 (1963).

4. Beaser, S.B.: Clinical states with decreased glucose tolerance. J. Amer. med. Ass. 199, 990-991 (1967).

5. Blotner, H.: Effect of prolonged physical inactivity on tolerance of sugar. Arch. intern. Med. 75, 39-44 (1945).

5. Blotner, H.: Effect of prolonged physical inactivity on tolerance of sugar. Arch. intern. Med. 75, 39-44 (1945).

6. Blotner, H.: Sugar tolerance tests Methods and ovaluation. Amer. J. dig. Dis. 14, 245-258 (1947).

7. Brandt, R.L.: Decreased carbohydrate tolerance in elderly patients. Geriatrics 15, 315-325 (1960).

8. Butterfield, W.J.H.: Summary of results of the Bedford Diabetes Survey. Proc. roy. Soc. Med. 57, 196$200(1964)$.

9. - In: Diabetes-Proceedings of the sixth congress of the international diabetes federation, p. 653. Amsterdam: Excerpta Medica Foundation. Ostman, J. (Stockholm), Milner, R.D.G. (Cambridge) 1969.

10. Chesrow, E.J., Bleyer, J.M.: The glucose tolerance test of the aged. Geriatries $9,276-282$ (1954).

11. - - Diabetes case finding among 1000 patients over 60. Geriatries 10, 479-486 (1955).

12. Conn, J.W.: Interpretation of the glucose tolerance test. The necessity of a standard preparatory diet. Amer. J. med. Sci. 199, 555-564 (1940).

13. - The prediabetic state in man. Definition, interpretation and implications. Diabetes 7, 347-357 (1958).

14. Deren, M. D.: Dextrose tolerance in the aged. J. Lab. clin. Med. 22, 1138-1141 (1937).

15. Fajans, S.S., Conn, J.W.: The early recognition of diabetes mellitus. Ann. N.Y. Acad. Sci. 82, 208-218 (1959).

16. Fitzgerald, M.G., Keen, H.: Diagnostic classification of diabetes. Lancet 1964 I, $1325-1326$.

17. Freychet, P., Tchobroutsky, G.: Journées de Diabétologie Hôtel-Dieu, p. 249-271. Paris: Editions médicales Flammarion 1968.

18. Geigy Tables Scientifiques, p. 634. Bâle: J.R. Geigy 1963 .

19. Goldberg, L., Luft, R. : A comparison of oral and intravenous dextrose tolerance tests in healthy subjects. Acta med. scand. 132, 201-222 (1948).

20. Gordon, T.: Glucose tolerance of adults, U.S. $1960-$ 1962: Diabetes prevalence and results of glucose tolerance test, by age and sex. Vital and health statistics, series 11, No. 2, Washington, U.S. Government Printing Office 1964.

21. Gottfried, S.P., Pelz, K.S., Clifford, R.C.: Carbohydrate metabolism in healthy old men and women over 70 years of age. Amer. J. med. Sci. 242, 475-480 (1961).

22. Hayner, N.S., K jelsberg, M.O., Epstein, F.H., Francis, T., Jx.: Carbohydrate tolerance and diabetes in a total community, Tecumseh, Michigan. Effects of age, sex and test conditions on one-hour glucose tolerance in adults. Diabetes 14, $413-423$ (1965).

23. Hecht, A., Weisenfeld, S., Goldner, M.G.: Factors influencing oral glucose tolerance: experience with chronically ill patients. Metabolism 10, 712-723 (1961).
24. Hoffman, W.S.: A rapid photoelectric method for the determination of glucose in blood and urine. J. biol. Chem. 120, 51-55 (1937).

25. Horvath, S.M., Wisotsky, R., Corwin, W.: The oral glucose tolerance test in old men. J. Geront. 2,25-30 (1947).

26. Joslin, E.P., Krall, L.P.: Treatment of diabetes mellitus. Ed. Joslin, Root, White, Marble, p. 18-46. 10th edition. Philadelphia: Lea \& Febiger 1959.

27. Keen, H.: The Bedford Survey : a critique of methods and findings. Proc. roy. Soc. Med. 57, 200-202 (1964).

28. Lambert, T.H., Johnson, R.B., Paul, G.R.: Glucose and cortisone-glucose tolerance in normal and "prediabetic" humans. Ann. intern. Med. 54, 916-923 (1961).

29. Lauvaux, J.P.: Hypoglycemies - Diagnostic et traitement dans la pratique médicale, p. $60-65$. Bruxelles: Presses Académiques Européennes 1969.

30. - Thys, O., Sternon, J.: Les comas hypoglycemiques par sulfamides antidiabetiques - à propos de 16 cas. Acta clin. belg., 23, 153-162 (1968).

31. Malaisse, W., Lauvaux, J.P.: Unpublished data.

32. Mosenthal, H.O., Barry, E.: Criteria for and inter pretation of normal glucose tolerance tests. Ann. in tern. Med. 33, 1175-1194 (1950).

33. Moyer, J.H., Womack, C.R.: Glucose tolerance: I. a comparison of 4 types of diagnostic tests in 103 control subjects and 26 patients with chemical diabetes. Amer. J. med. Sci. 219, $161-173$ (1950).

34. O'Sullivan, J.B., Mahan, C.M.: Prospective study of 352 young patients with chemical diabetes. New Engl. J. Med. 278, 1038-1041 (1968).

35. Pequignot, H., De Traverse, P.M., Deuil, R., Etienne J.P., Gremer, G., Pierrot-Deseilligny, E.: Test de tolérance au glucose et troubles glyco-régulateurs chez le vieillard. Path. Biol. 9, 281-290 (1961).

36. Pickering, G.W.: High blood pressure. Ch. 8 p. 154183. London: J. \& A. Churchill Ltd. 1955.

37. Pozefsky, J.L., Colker, J.L., Langs, H.M., Andres, R.: The cortisone glucose tolerance test. Ann. intern Med. 6, 988-997 (1965).

38. Rapport d'un Comite D'Experts de L'O.M.S. - Le Diabète Sucré. Org. Mond. Santé. Sér. Rapp. Techn. 310, p. 7-9. Genève: O.M.S. 1965.

39. Report of a Working Party. Glucose tolerance and glycosuria in the general population. Brit. med. J. 1963 II, 655-659.

40. Report of the Committee on Statistics. Standardization of the oral glucose tolerance test. Diabetes 18, 299-307 (1969).

41. Rosenberg, C. A. : Aging and endocrine function - The pancreas. J. Amer. Geriat. Soc. 14, 947-953 (1966).

42. Ryan, W.G., Economou, P.G., Schwartz, T.B.: Intravenous glucose tolerance test in an industrial population. (Controls, subjects with coronary heart disease and relatives of diabetics). Diabetes 16, $171-174$ (1967).

43. Short, J.J., Johnson, H.J.: Glucose tolerance in relation to weight and age. A study of 541 cases -49 th annual meeting of the association of life insurance medical directors of America - October 1938, p. 237-257. New York: Records of the Life Extension Institute 1938.

44. Silverstone, F.A., Brandfonbrener, M., Shock, N.W., Yiengst, M.J.: Age differences in the intravenous glucose tolerance tests and the response to insulin. $J$. clin. Invest. 36, 504-514 (1957).

45. Smith, L.E.: Glucose tolerance in the aged. J. Geront. 3, $66-69(1948)$ 
46. Streeten, D.H.P., Gerstein, M.M., Marmor, B.M., Doisy, R.J.: Reduced glucose tolerance in elderly human subjects. Diabetes 14, 579-583 (1965).

47. Vague, J., Codaccioni, J.L., Vague, P., Teitelbaum, M.: Nouveaux résultats comparés des épreuves d'hyperglycémie provoquée par voie orale, avec ou sans cortisone et par voie veineuse. Le Diabète 13, 55-59 (1965).

48. Vinik, A., Jackson, W.P.V.: Hyperglycemia in the elderly. Is it diabetes? Diabetes 17, 348 (1968).

49. West, K.M., Wulff, J.A., Reigel, D.G., Fitzgerald, D. T.: Oral carbohydrate tolerance tests. Arch. intern. Med. 113, $641-648$ (1964).
50. Wilder, R.M.: The unknown diabetic and how to recognize him. J. Amer. med. Ass. 138, 349-351 (1948).

51. Wilkerson, H.L.C., Krall, L.P.: Diabetes in a New England town. Report of four year progress study of the Oxford, Mass., Diabetes survey of 1946-1947. J. Amer. med. Ass. 152, $1322-1329$ (1953).

Dr. J.P. Lauvaux Clinique Médicale

Hôpital Universitaire St. Pierre

Université Libre de Bruxelles

Bruxelles, Belgique 